\title{
Organizational Structure and Financial Performance of Investment Groups Participating in Kenyan Capital Markets
}

\author{
Samuel O. Onyuma \\ School of Business \& Economics, Laikipia University, Kenya
}

\begin{abstract}
The idea behind collective investment through group formation has shape the investment growth in Kenya. Individuals come together to form homogeneous or heterogeneous groups to enable them raise adequate investment capital. They invest in an array of assets and portray different financial performance. However, there is scanty evidence on how the form in which an investment group is organized affects its financial performance. Therefore, the objective of the study was to assess the effect of organizational structure on the financial performance of investment groups in Kenya which invests in capital market securities. Descriptive survey design was used and stratified and simple random sampling techniques were used to select a sample of 130 investment group members and 130 investment groups, which invest in capital markets. Data was analyzed using both descriptive and inferential statistics. The results indicated that group organizational structure generally positively and significantly affects financial performance of investment groups in Kenya. The group organization structure dimensions having a significant positive effect on group financial performance were organization form, financial management, accounting and auditing. The study recommends that policies should be created to encourage incorporation and formalization of investment groups as a strategy to spruce up their financial performance. Registrar of groups should insist on registration only for groups which are registered for tax and with articles and memorandum of associations detailing clear rules for joining, exit and sharing of group profits.
\end{abstract}

Keywords: Investment Group Organization Structure, Group Financial Performance, Chama Investments, Kenya Association of Investment Groups.

DOI: $10.7176 / \mathrm{JPID} / 54-05$

Publication date:May $31^{\text {st }} 2020$

\section{Introduction}

Many developing economies such as those from African have enacted and encouraged financial schemes meant to promote savings and investments among low income earners. These schemes range from cooperative societies, microfinance initiatives to the most recent, investment groups - a form of joint financial groupings. In Kenya, the emergence of the capital markets as a new way of investment, according to Onyuma \& Kibet (2017), has encouraged many low income earners to form these groups. Investment groups have become more popular with Kenyans. Unlike merry-go-rounds, where members collect money monthly and give it to one member on a rotational basis, an investment group saves money every month but instead of the collected money being given to a member, the group invests the money jointly. These investments may be done in shares, bonds, derivatives, real estate, among many other investment opportunities.

An investment group is therefore any collection of individuals or legal persons in any form whatsoever including but not limited to societies registered under the Societies Act, Partnerships and Limited Liability Companies, whose objectives is the pooling together of capital with the aim of using such resources for investment purposes. It is important that members decide how the group is to be recognized before the law, since the law has not made any special provision for these types of entities. There are two common options of organizing and formalizing an investment group, according to Wainaina (2012), a limited liability company or a partnership.

An investment group represents an archetypal example of an organization in which interactional processes can be observed. Such groups are composed of people of different business experiences, gender, occupational and business training backgrounds (Harrington, 2010), and with varied dimensions of organizational structure as well as formalization. Most investment groups in Kenya are informal (KAIG, 2014), with informality referring to the legal economic activity taking place below the radar of government (Oviedo, 2009). Organizational structure refers to the formalization process whereby a previously non-compliant investment group becomes integrated into formal sector and through which it obtains a PIN certificate in the name of the enterprise for taxation purposes. A decision to become formal is arrived at after a group compares its perceived costs of being formal including both initial registration and ongoing costs like tax payments, with perceived benefits, for instance access to credits for expansion (De Mel, McKenzie \& Woodruff, 2011). These benefits are clearly driving the decision to formalize businesses (Gelb, Mengistae, Ramachandran, \& Shah, 2009).

Some investment groups start initially as Self-help groups, but eventually transform to investment groups (KAIG 2014) but without registering either as a limited liability company or as a partnership. These are Chamas registered also as Self-help groups, where members with a common goal come together and form a group aimed at improving their personal welfare. These groups are also referred to as mutual help or merry-go-rounds. In Kenya, 
they are registered under the Ministry of Labour Social Protection, State Department of Social protection. Most investment groups fall into the category of Small and Micro Enterprises (SMEs). Their small size and flexibility permits them to specialize in narrow niches that are generally less interesting for larger enterprises (Kraus, 2007). Such informal groups embody a set of relationships and values that formal services are not able to offer. They show how managing money involves more than financial management but the creation of significant social value. This is why they are of enduring importance in people's lives (Johnson, 2018).

Investment groups offer a number of advantages to members. They help to promote both savings and investments because the group is usually committed to regular saving and long term investing. Member, who are new to investing, learn a lot from more experienced ones and those who lack time to research investment options share in the research done by others. Even though members contribute little money the bundling effect of the group enables them to undertake big investments (Mwanzia, 2018), which otherwise they would not be able to do individually.

Investment groups also generate capital resources for economic development. They assist in consolidating unharnessed resources by known formal financial system in an economy. Bearing the burden of risk associated with investment group, formal financial institutions fails to lend to these groups. Members choose to come together to raise needed capital for investment. The basis of their grouping is the mutual understanding for a single-handed goal. The organization of one investment group assist in investment process since a single individual may have less than the required cash outlay. The virtue of coming together assist not only on the raising of needed capital and enjoyment of return but also risk sharing. Investment groups use this idea to lobby more members to join the group to raise more capital and invest in a variety of investments. This will enable them reduce the risk exposure compared to groups investing on few project constrained by capital availability.

The return on investment agitate individual member to be part of the investment group and contribute a share of capital to enjoy the return. This is the case when a member compare the cumulative advantages of investing as a group as opposed to individual investment. It is beneficial to determine how these investment groups perform when they are formalized since such groups may have added advantages than those that are not formalized. Currently, there is lack of information on how transition from informality to legal organizational structure through formalization can benefit an investment group in financial terms, especially those which participate in capital markets investments. The purpose of the study was to assess the effect of organizational structure on the financial performance of investment groups in Kenya which invests in capital market securities.

\section{Reviewed Literature}

\subsection{Kenyan Literature on Investment Groups}

In the Kenya's Vision 2030 development blueprint, under the financial services sector of the economic pillar, capital mobilization to raise funds for investment is expected to play a critical role in the anticipated economic growth. Investment groups are formed with the aim of growing and maximizing wealth for their members. In their book titled investment groups and their performance, Mwangi \& Njeru (2015) notes that investment groups have gained great popularity in Kenya with many people pooling resources to invest jointly for greater investment returns. They thus continue to contribute greatly to the economic and social well-being of millions of people. However, some investment groups have had financial challenges, making it difficult for them to be sustainable. It is against this background that this study ventured to assess how the organizational structure and formalization affect the financial performance of investment groups in Kenya.

Literature on investment groups is still thin in Africa generally and specifically in Kenya. The following is a review of the few studies in this area. Nderitu (2018) assessed the determinants of growth in wealth of investment groups in Kenya by looking at financial literacy, portfolio diversification, capital structure, and group governance. The study showed that all the above determinants of growth had significant influence on growth in wealth, and group size had a moderating effect on the relationship between these determinants and growth in wealth of investment groups. Similarly, Nderitu, Njeru \& Waiganjo (2017a) assessed the influence of portfolio diversification on growth in wealth of investment groups in Kenya. The study showed that there was a positive and significant relationship between portfolio diversification and growth in wealth of investment groups. The implication is that portfolio diversification is key to growth in wealth of investment groups, thus investment groups need to diversify their portfolio to create more wealth and strengthen their financial base. In addition, Nderitu, Njeru \& Waiganjo (2017b) studied the influence of financial literacy on growth in wealth of investment groups in Kenya. The study findings indicate that there was a positive and significant relationship between financial literacy and growth in wealth of investment groups. This implies that financial literacy is key to growth in financial wealth of investment groups.

A study on how real estate investment strategies - buy and hold, own and operate, development strategy affect the financial performance of investment groups in Kenya by Mbogo (2016) found a positive correlation between financial performance and all investment strategies explored specifically buy and hold strategy and own and operate posting results of great effect on financial performance. Furthermore, Ogutu (2014) studied the 
influence of investment groups on creation of small and medium size enterprises in Nairobi County in Kenya. Using a descriptive survey design, study concluded that investment groups highly influence the formation of small and medium enterprises and this was achieved through resource mobilization, sharing of business ideas, spreading risks and taking advantage of social networks of group members.

Moreover, Icharia \& Kamure (2014) establish factors influencing wealth creation in investment groups in Nairobi County in Kenya, and found that strategic planning and management and execution of investments significantly explained the wealth creation among such groups. Lastly, Muturi (2012) conducted a study on determinants of participation in rotating savings and credit associations (ROSCAs) in urban informal settlements of Mathare Slums in Nairobi using a multi-dimensional model and found that participation in ROSCAs is for varied motives, the main ones being saving, insurance, keeping away money from spouses and socialization. It is clear that the above studies have not covered the important aspect of how the groups are organized in terms of structure, form and the extent to which an investment group has taken a deliberate attempt to formalize its operations through registration, taxation, accounting and auditing, and financial management. Financial performance is defined as a measure of how efficient a firm utilizes its assets to generate revenues. The reason for determining the financial performance is to examine the direction in which an organization is moving and whether it is operating efficiently and effectively.

\subsection{Organizational Structure and Group Financial Performance}

Organizational structure in this study encompasses the dimensions of organizational form as well as the formalization. When the government taxes the income of corporate firms at a different rate than non-corporate firms, taxes can play an important role in a firm's choice of organizational form. The sensitivity of the organizational form decision to tax rates provides a key indicator of the distortion created by the corporate income tax. The limited liability company can replace the general partnership with a business that has all of the advantages of the partnership, but also provides owners with limited liability. The limited liability company, according to Chrisman (2009), is the most commonly formed new business entity in the United States. Furthermore, Guinnane, Harris, Lamoreaux, \& Rosenthal (2007) has challenged the idea that the corporation is a globally superior form of business organization. Although the corporation had important advantages over the main alternative form of organization like partnerships, it also had disadvantages that limits its appeal to micro and small enterprises, such as investment groups.

Irrespective of the organizational form, financial management is one of the key aspects of the well-being and survival of any business. There is a clear evidence that three important core financial management components are used by the MSEs namely financial planning and control, financial accounting and working capital management. Large corporations have reaped the benefits of following best practice in financial and management accounting to become more competitive. Such best practice can be used as a benchmark to improve performance in micro and small enterprises (Hoe, 2010), such as investment groups.

Firms that adhere to appropriate financial planning prove to perform better. Like large firms, MSEs such as investment groups, also require adequate and sophisticated management accounting techniques and systems to manage scarce resources hence better financial performance (Nandan, 2010). With financial models in place, firms can adequately address financial challenges with a lot of ease. Models relates with strategic planning, best practice financial and cost accounting practices, and financial effectiveness (Zaman \& Gadenne, 2002). Cash flows of the firm need to be managed since it indicates the ability of the firm to acquire more capital resources (Deakins, Logan $\&$ Steele, 2001). The issue of finance has been identified as an immediate reason why businesses in developing countries fail to start or to progress (Abor, 2007).

Most MSEs, including investment groups, draw on external support, and their main advisors are external accountants. In recent years there has been much discussion regarding the burdens imposed on such small firms by administrative requirements and in particular, those imposed by accounting requirements (Keasey \& Short, 1990; Bennett \& Robson, 1999). However, an effective and proper accounting system has a profound impact in successful auditing of such as investment groups and other MSEs and by extension on the performances of the firms. Audit helps both shareholders and stakeholders to make informed decisions about future directions, based on how the company is performing (Olasupo, Sorunke \& Olawuyi, 2016). Similarly, voluntary purchase of business advice jointly with auditing have been found to improve MSE performance (Carey, 2015).

Developing economies are now following the IFRS, which were developed in advanced economies. Tyrrall, Woodward, \& Rakhimbekova, (2007) examined the relevance and implementation of IFRS to the emerging economy of Kazakhstan from independence in 1991 to 2006. This study indicated that IFRS relevance is likely to increase as Kazakh economic development continues although its implementation was problematic. IFRS are suitable for all enterprises, but their application in case of MSEs would be very expensive and could significantly increase compliance costs of taxation. Bohušová (2014) discussed the IFRS modifications, which should be done in case of MSE s. IFRS for MSEs should be designed to apply to the general purpose harmonized financial statements and other financial reporting. 
For IFRS to be acceptable to MSEs, the gains should exceed the costs of IFRS for MSE application. Nerudova \& Bohusova (2008) assessed the possibility of introduction of IFRS for MSE in the Czech enterprises. Based on the questionnaires, respondents were highly interested in the costs and gains of IFRS for MSE application. The study found that the first application of IFRS for MSE in the Czech, was expensive and time demanding, due to the different philosophy, principles and methodology of recording used in IFSR for MSE. A few people also consider that the IFRS for MSEs in its current form is adequate. Bunea Sacarin \& Mihaela (2012) investigated the attitude of Romanian professional accountants about the financial reporting of MSEs. Data was collected through questionnaires on a sample of 190 accountants. The results indicate that more than a half of respondents consider that the current regulations do not provide a reasonable level of simplification for MSEs, which could also apply in the case of investment groups.

Despite international interest, academic research investigating the accounting and financial reporting needs of small enterprises, such as investment groups, remains relatively scarce. Sian \& Roberts (2009) assessed the potential demand for and usefulness of reporting guidelines specifically designed for small enterprises in the UK. Data were gathered from accountants providing services to these enterprises and the owners of such enterprises using postal questionnaires. It was found that most of the enterprises produce accounting records, often based on computerized packages and that most small enterprise owners rely on their accountants to prepare their financial statements and are often left bewildered by the complexity of the information provided. The findings also indicated that some aspects of existing regulations were too complex, indicating that regulators need to carefully consider the possibility of developing guidance for the small business entities.

Increasing the complexity of reporting requirements for small companies would not necessarily lead to more accurate reporting. Fearnley \& Hines (2007) evaluated the changing attitudes to IFRS, and the accounting model being adopted, particularly focusing on the problems facing smaller companies. The study employed qualitative analysis of data from two main sources: first, a series of interviews with financially literate individuals before IFRS was implemented in the UK; and second, from responses to consultations on the future of financial reporting for non-listed entities. The conclusion was that one reasonably coherent system of accounting regulation would be much harder to achieve under IFRS, which potentially leaves a large number of diverse organizations outside the scope of full IFRS.

Formalization affects investment groups in various ways. De Mel, McKenzie, \& Woodruff (2013) conducted a field experiment in Sri Lanka in order to measure the latent demand for formalization, and the consequences that formalizing has on informal firms which provided incentives for informal firms to formalize. They concluded that formalized firms do more advertising and are more likely to use receipt books, but don't appear to get the more touted benefits of formalizing such as increased access to credit, obtaining government contracts or participating in government programs.

Micro and small businesses are under no legal obligation to produce accounting reports, but must comply with taxation provisions. However, it is clear that they operate under a heavy tax burden which prohibits their growth and development (Mwangi, Nganga, Ullah, Shah, Rehman, Hussain \& Man, 2011). Hansford \& Hasseldine (2012) evaluated and compared tax compliance costs affecting micro and small-scale enterprises in UK and found out that there is negative relation between the size of the enterprise and the amount of compliance costs of taxation. Rand \& Torm (2012) examined the relationship between legal status and firm level outcomes in micro, small and medium manufacturing enterprises in Vietnam. They sought to get a better understanding of the characteristics and dynamics of the informal sector, as well as the perceived benefits associated with formalization and suggested that registration of businesses lead to an increase in profits and investments for Vietnamese MSEs.

Using firm-level data from Mexico, Fajnzylber et al. (2009) investigated the firm characteristics associated with participation in credit markets, access to training, tax payments and membership in business associations. The results showed that being formal increases profits by at least 20 per cent. In another study, Fajnzylber et al. (2011) investigated whether high tax rates and complex tax regulations really constitute a barrier to the formalization of micro-firms, and if formalization improves firm performance. The study exploited an extensive Brazilian micro-enterprise survey and the 1996 introduction of a business tax reduction and simplification scheme - the Integrated System for the Payment of Taxes and Social Security Contributions of Micro and Small Enterprises. The results indicated that there were much higher revenues, employment and profits among firms, which register.

According to Fajnzylber et al. (2009), small firms that borrow from formal or informal sources and those that pay taxes are significantly more likely to stay in business. Tax advantages derived from debt would lead firms to be completely financed through debt. The interest payments associated with debt are tax deductible, while payments associated with equity, such as dividends, are not tax deductible. Therefore, this tax effect encourages debt use by the firm (Modigliani \& Miller, 1963). Jaramillo (2009) however had a different conclusion from his study, which analyzed the demand for formality by using experimental data from micro firms in downtown Lima. The findings showed that for some firms formalization might not be desirable at any cost. This is likely to be associated with the recurrent costs of being formal, the low perceived value of the benefits of formalization, and the limited growth perspectives of these firms. 
McKenzie \& Sakho (2010) estimated the impact of registering for taxes on firm profits in Bolivia, the country with the highest levels of informality in Latin America. The sample frame consisted of a geographic information database, based on a census of economic establishments. They found that tax registration appeared to increase profits for the mid-sized firms, but to lower profits for both the marginal smaller and larger firms, in contrast to the standard view that formality increases profits. How these formalization and organizational structure dimensions may interact with financial performance is still not clear in available in the Kenya literature.

\section{Methodology}

This study assessed the effect of organizational structure dimensions on financial performance of investment groups. Guided by descriptive survey research design, the study was able to achieve an in depth investigation of the phenomenon that was under study as the design gave a wide coverage within a short time, as well as a description of the state of affairs, as it exists. The study targeted the population of registered groups in Nakuru County of 17,945 by the State Department of Social Security and Protection. A sample of 130 members and 130 groups were selected and primary data collected these sources using questionnaires which consisted of a series of questions and other prompts for gathering information. The questionnaire was used to get information on dimensions of group structure through formalization process.

The collected data was analyzed using a descriptive statistics as well as inferential statistical analysis via regression analysis to establish the effect of group structure on financial performance.

The following regression model was specified and used for the analysis.

$\mathrm{Y}=\beta_{0}+\beta_{1} \mathrm{RGST}_{\mathrm{i}}+\beta_{2} \mathrm{FMGT}_{\mathrm{i}}+\beta_{3} \mathrm{ACAD}_{\mathrm{i}}+\beta_{4} \mathrm{FNRP}_{\mathrm{i}}+\beta_{5} \mathrm{TAXR}_{\mathrm{i}}+\mathrm{u}_{\mathrm{i}}$

Where:

$\mathrm{Y}=$ Financial Performance captured as ROI and measured as net income divided by invested capital, given as a percentage

$\mathrm{RGST}_{\mathrm{i}}=$ Nature of registration for the $i$ th group, coded as: 1 - incorporated as a limited liability company, 2 registered as a partnership, 3 registered as Self Help group.

$\mathrm{FMGT}_{\mathrm{i}}=$ Financial management for the $i$ th group, coded as: $1-$ group performs financial management, zero otherwise.

$\mathrm{ACAD}_{\mathrm{i}}=$ Accounting and auditing for the $i$ th group, coded as: 1- group's books of accounts are audited, zero otherwise.

$\mathrm{FNRP}_{\mathrm{i}}=$ Financial reporting for the $i$ th group, coded as: 1 - group produces annual financial statements, zero otherwise.

$\mathrm{TAXC}_{\mathrm{i}}=$ Tax returns/compliance for the $i$ th group, coded as: $1-$ group makes tax returns, zero otherwise.

$\mathrm{B}_{0}-\beta_{5}=$ Are parameters to be estimated.

$\mathrm{u}_{\mathrm{i}}=\quad$ is the error term, financial performance that cannot be explained by the model.

The significance of the model was assessed by comparing the p-value of the F-statistic with the level of significance at an alpha of 0.05 .

\section{Discussion of Findings}

Results obtained from the descriptive analysis, not presented here, indicate that about 66.3 percent of the sampled investment group members had invested for a period of less than 4 years, while 33.7 percent had invested for a period more than five years. About 48 percent of the sampled group members were males while females accounted for 52 percent. This implies a gender imbalance of the investment groups in the study area. In addition, the findings further reveal that 49 percent of investment group members were entrepreneurs, 17.3 percent were teacher, while 13.3 percent were accountants. The implication is that investment groups with members from different occupations can easily invest in different industries. Investment groups had also spread their investments across the four investment portfolios. Real estate accounted for 44.5 percent of the groups' investment portfolio, financial securities such as listed shares and government and corporate bonds accounted for 42.8 percent, with the highest investment being in the real estate and lowest in both government and corporate bonds. The growth in capital market activities has attracted many investment groups to capital markets securities investments, a trend which, according to Onyuma \& Ochieng' (2017), is expected to contribute to more investor wealth maximization.

The findings generally show that group formalization is significant positive effect on group financial performance. It is important to look into how variability in financial performance is explained by group organizational structure and formalization dimensions. For the regression purposes, mean representing each of the dimension - organizational form, financial management, accounting and auditing, financial reporting and tax returns - was computed and regressed against financial performance mean. From the data analysis, the results indicate an $\mathrm{R}^{2}$ of 0.980 and adjusted $\mathrm{R}^{2}$ value of 0.979 , implying that about 97.9 percent of the total variation in group financial performance was explained by changes in dimensions of group structure and formalization. An analysis of variance revealed that the overall model was statistically significant as supported by an F-statistic of $1023.349(\mathrm{p}$ value $=0.000)$. 
Findings contained in Table 1, show the beta values for each variable and their level of significances. Table 1: Effect of Group Organizational Structure and Formalization on Financial Performance

\begin{tabular}{|c|c|c|c|c|c|}
\hline & \multicolumn{2}{|c|}{$\begin{array}{c}\text { Unstandardized } \\
\text { Coefficients }\end{array}$} & \multirow{2}{*}{$\begin{array}{c}\text { Standardized } \\
\text { Coefficients } \\
\text { Beta } \\
\end{array}$} & \multirow[t]{2}{*}{$\mathrm{t}$} & \multirow[t]{2}{*}{ Sig. } \\
\hline & $\mathrm{B}$ & Std. Error & & & \\
\hline (Constant) & 2.073 & .641 & & 3.235 & .002 \\
\hline RGST & .604 & .038 & .822 & 15.906 & .000 \\
\hline FMGT & .167 & .018 & 441 & 9.404 & .000 \\
\hline ACAD & -.096 & .022 & -.245 & -4.288 & .000 \\
\hline FNRP & -.023 & .021 & -.055 & -1.086 & .028 \\
\hline TAXC & .014 & .007 & .038 & 1.980 & .051 \\
\hline
\end{tabular}

a. Dependent Variable: Return on Investment

The results indicate the coefficient for organizational form to be $0.604(\mathrm{p}=0.00)$ which was statistically significant at the 5 per cent level of significance. This indicates that a unit change in group organizational form causes a variation of 0.604 units in financial performance. Investment groups are formalized by being registered to pay taxes at group level. Investment groups that are formalized and registered as limited liability company have to pay corporate tax to the government. Groups which are registered as self-help group or as partnerships are taxed at individual member level. The results of this study agrees with that of Goolsbee (2004) who concluded that, the double taxation issue bears quite heavily on the choice of organizational form. The income tax authorities require that a group's books of accounts be audited for tax purpose. This forces an investment group to adopt the best financial and cost accounting practices which leads to financial effectiveness Zaman \& Gadenne (2002). Formal firms therefore are more productive and profitable. The study findings also support the study by Chrisman (2009) who concluded that Limited Liability Company was the most profitable business entity in the United States.

The results further show that the coefficient for financial management was $0.167(\mathrm{p}=0.00)$. This was statistically significant at the 5 percent level of significance. This implies that a unit change in the level of financial management activities leads to 0.167 unit variations in the level of group financial performance. These results agree with that of Nandan (2010), who argued that like large firms, MSEs also require adequate and also sophisticated management accounting techniques and systems to better manage scarce resources hence better financial performance. Cash management, being a component of financial management is very important because access to finance for expansion of investments is needed for better financial performance of investment groups, according to Abor (2007). The results of this study also supports that by Kinyua (2005) who found that net profit after access of credit from MFIs was more than the net profit before access of credit.

Moreover, the results show that the coefficient for accounting and auditing was $-0.096(\mathrm{p}=0.00)$ which was statistically significant at the 5 per cent level of significance. This implies that a unit decrease in the quality and level of accounting and auditing of books of group accounts leads to 0.096 unit increase in financial performance. Most investment groups operate as small firms and if they were to employ accountants and auditors for administrative requirements, and in particular those imposed by accounting requirements they would have to pay a lot in terms of salaries and fees. The finding is also in line with other studies such as Keasey \& Short (1990) and Berry et al. (2012) who found that there is a relative burden of accounts perceived by small firms which makes the perceived value of accountants and auditors relatively low.

In terms of financial reporting, the results indicate that the coefficient is $-0.023(\mathrm{p}=0.028)$. This implies that a unit increase in financial reporting standards leads to 0.023 unit increase in financial performance. Financial reporting requirements can impose a significant burden on smaller enterprises such as investment groups. The study findings supports Tyrrall et al. (2007) study that application of IFRS in case of MSEs would be very expensive and could significantly increase compliance costs of taxation, thereby reducing their profits. The results also support those by Bunea et al., (2012), who reported that the current regulations do not provide a reasonable level of simplification for the financial reporting of micro and small enterprises.

Finally, the study found that the coefficient for tax compliance was $0.014(\mathrm{p}=0.051)$, implying that a unit increase in tax returns leads to 0.014 unit increase in financial performance. But this finding was not statistically significant at the 5 percent level but only at the 10 percent significance level. This study supports the findings that that keeping proper accounting records, for the purposes of tax returns, leads to better financial management through which costs are minimized and profits maximized (Rand \&Tom 2012). The finding of this study also concurs with that of Fajnzylber et al. (2011) who found that registration of business for tax purposes leads to an increase in profits. Another reason for improved financial performance is that interest payments on debt is deductible tax deductible, hence an improved financial performance (Fajnzylber et al., 2009).

\section{CONCLUSION \& POLICY PRESCRIPTION}

Group organizational form and formalization status has strong positive significant effect on group financial performance. Only registered groups are capable of opening CDS accounts with CDSC, which would then enable 
them to participate in investments in the capital markets. Formalized investment groups must comply with tax provisions, and this is only possible if they have KRA income tax PIN certificates. This forces them to keep proper books of accounts and to utilize services of external financial consultants. With good financial management practices, formalized investment groups can therefore access credit for expansions because commercial banks normally evaluate them on the basis of a checklist, including audited financial statements.

Investment group's membership comes along with certain responsibilities such as the commitment to attend meetings and hold leadership positions. Probably, the biggest challenge faced by most investment groups is the issue of values, as the group is made up of members with different sets of values and it is feasible that there will not be consensus on all issues, as has been shown by Onyuma (2020). Some groups agree ahead of time on values to be followed and whenever there is conflict the majority decision rules. People interested in forming an investment group need to properly understand and handle areas such as the legal form of the group, accounting policy, investment strategy and other general group's policy and rules.

Most investment groups are registered as partnerships, mainly due to tax considerations and the fact that they are easy to form. Investment group can also be formed as private limited liability companies or cooperative societies. However when choosing what form of registration to take, it is important to consider regulatory and tax requirements, as well as the legal protection it will offer. Proper accounting is also vital for successful performance of any investment group. A proper accounting policy ensures that all club's transactions are well documented. Accountability is an absolute must. Constant financial reporting will not only help members understand the financial status of their group, but also act as a motivator where positive profitability is indicative.

Developing and regularly reviewing the group's investment strategy is vital too. This involves deciding the amount to be invested in any particular financial security or asset, depending on the group objectives and the risk levels agreed on. For a start, investment groups usually invest in largely low risk to medium risk securities, as has been shown by Kirui \& Onyuma (2019). As they grow they move into high risk investment portfolios. The group's stockbroker or investment advisors can advise on the winning strategy to be taken by the group considering the market conditions.

Furthermore, investment groups should have clear rules on issues like joining and leaving the group, payment of dividends and member contributions. This will enable proper operation of the group, avoid inviting members of uncorrelated objectives to the group and evade a cash crunch incase a member decides to leave. Such rules may change from time to time depending on a decision passed by the agreed majority threshold of members. Investment group are a sociable way to make investment, great way to brainstorm ideas and share knowledge, and can be very good for members' financial endowment. Nevertheless, as is common with business outfits which mixes friendship and money, perhaps it is important that members understand the ground rules from the initiation. That means making sure that all of them are in the group for the same fiduciary reasons, and then all that remains is to select viable investments which will spruce up group's financial performance.

Therefore, efforts to promote group financial performance in investment groups must put more emphasis on formalization of the group structure so that they register with tax authority, and linked to accounting and audit firms whose fee structure are affordable to such investment groups. The government through the Registrar of Business should design a category of registering groups as limited liability companies for small firms. This might also call for proper group officials' education on basic book-keeping and tax filling skills.

\section{References}

Abor, J. (2007). Debt policy and performance of SMEs: Evidence from Ghanaian and South African firms. The Journal of Risk Finance, 8(4): 364-379.

Bennett, R. J., \& Robson, P. J. (1999). The use of external business advice by SMEs in Britain. Entrepreneurship \& Regional Development, 11(2): 155-180.

Bohušová, H. (2014). The possible ways to IFRS for SME development. Acta Universitatis Agriculturae et Silviculturae Mendelianae Brunensis, 55(6): 17-26.

Bunea, S., Sacarin, M., \& Mihaela, M. I. N. U. (2012). Romanian professional accountants' perception on the differential financial reporting for small and medium-sized enterprises. Accounting and Management Information Systems, 11(1): 27.

Carey, P. J. (2015). External accountants' business advice and SME performance. Pacific Accounting Review, 27(2): 166-188

Chrisman, R. D. (2009). LLCs are the new king of the hill: An empirical study of the number of new LLCs, corporations, and LPs formed in the United States Between 2004 and 2007 and how LLCs were taxed for tax years 2002-2006. Fordham Journal of Corporate \& Financial Law, 15: 459.

De Mel, S., McKenzie, D., \& Woodruff, C. (2011). What is the cost of formality? Experimentally estimating the demand for formalization. Mimeo.

De Mel, S., McKenzie, D., \& Woodruff, C. (2013). The demand for, and consequences of, formalization among informal firms in Sri Lanka. American Economic Journal: Applied Economics, 5(2): 122-50. 
Deakins, D., Logan, D., \& Steele, L. (2001). The financial management of the small enterprise. London: Certified Accountants Educational Trust.

Fajnzylber, P., Maloney, W. F., \& Montes-Rojas, G. V. (2009). Releasing constraints to growth or pushing on a string? Policies and performance of Mexican micro-firms. The Journal of Development Studies, 45:10271047.

Fajnzylber, P., Maloney, W. F., \& Montes-Rojas, G. V. (2011). Does formality improve micro-firm performance? Evidence from the Brazilian SIMPLES program. Journal of Development Economics, 94(2), 262-276.

Fearnley, S., \& Hines, T. (2007). How IFRS has destabilised financial reporting for UK non-listed entities. Journal of financial regulation and compliance, 15(4): 394-408.

Gelb, A., Mengistae, T., Ramachandran, V., \& Shah, M. K. (2009). To formalize or not to formalize? Comparisons of microenterprise data from southern and east Africa. CGD Working Paper No. 175. Washington, DC, Center for Global Development

Goolsbee, A. (2004). The impact of the corporate income tax: evidence from state organizational form data. Journal of Public Economics, 88(11): 2283-2299.

Guinnane, T., Harris, R., Lamoreaux, N. R., \& Rosenthal, J. L. (2007). Putting the corporation in its place. Enterprise and Society, 8(03): 687-729.

Hansford, A. and Hasseldine, J. (2012). Tax compliance costs of small and medium-sized enterprises (SMEs): The case of the UK. eJournal of Tax Research, 10: 288-303.

Harrington, B. (2010). Pop finance: Investment clubs and the new investor populism. Princeton University Press.

Hoe, C. H. (2010). Financial management practices: an in-depth study among the CEOs of Small and Medium Enterprises (SMEs). International Review of Business Research Papers, 6(6): 13-35.

Icharia, A. \& Kamure B. (2014). Factors influencing wealth creation in investment groups in Nairobi County, Kenya. Strategic Journal of Business \& Change Management, 2(18): 339-361.

Jaramillo, M. (2009). Is there demand for formality among informal firms? Evidence from microfirms in downtown Lima. Bonn: German Development Institute Discussion Paper 12/2009, German Development Institute.

Johnson, S. (2018). What can financial providers learn from chamas? FSDkenya Blog, Posted on March $26^{\text {th }}$. https://fsdkenya.org/blog/what-can-financial-providers-learn-from-chamas/

KAG (Kenya Association of Investment Groups) (2014). The Chama Handbook, 2nd Edn. Nairobi: Kenya Association of Investment Groups.

Keasey, K., \& Short, H. (1990). The accounting burdens facing small firms: an empirical research note. Accounting and Business Research, 20(80): 307-313.

Kenya Association of Investment Groups KAIG. (2014). The Chama handbook $2^{\text {nd }}$ Edition Nairobi.

Kirui, R. \& Onyuma, S. O. (2019) Effect of Group Composition and Formalization on Financial Performance of Investment Groups in Kenya. International Journal of Economics, Finance and Management Sciences, 7, (2): 65-73.

Kraus, S. A. S. C. H. A. (2007). Strategic planning in new ventures and young SMEs. $21^{\text {st }}$ Century ManagementA Reference Handbook, 73-81.

Mbogo, P. W. (2016). Effect of real estate investment strategies on financial performance of investment groups in Kenya. Unpublished Masters Thesis, (University of Nairobi).

McKenzie, D., \& Sakho, Y. S. (2010). Does it pay firms to register for taxes? The impact of formality on firm profitability. Journal of Development Economics, 91(1): 15-24.

Modigliani, F., \& Miller, M. H. (1963). Corporate income taxes and the cost of capital: a correction. The American economic review, 53(3): 433-443.

Muturi, W. M. (2014). Determinants of participation in rotating savings and credit associations in urban informal settlements: Evidence from Mathare Slums, Nairobi, (Unpublished PhD thesis JKUAT).

Mwangi, G. \& Njeru, A. (2015). Investment groups and their performance. Scholars' Press, Wood Dale, IL, U.S.A.

Mwangi, M. J., Nganga, I., Ullah, H., Shah, A., Rehman, S., Hussain, \& Man, M. (2011). Taxation and SMEs sector growth. Asian Journal of Business and Management Sciences ISSN, 2047-2528.

Mwanza, K (2018). Investment clubs: A social approach to investing. African Executive, http://www.africanexecutive.com/modules/magazine/articles.php?article=

Nandan, R. (2010). Management accounting needs of SMEs and the role of professional accountants: A renewed research agenda. Journal of applied management accounting research, 8(1): 65-78.

Nderitu, M. W. (2018) Determinants of growth in wealth of investment groups in Kenya. Unpublished PhD Thesis, (Jomo Kenyatta University of Agriculture \& Technology).

Nderitu, M., Njeru, A. K. \& Waiganjo, E. W. (2017a). Influence of portfolio diversification on growth in wealth of investment groups in Kenya. European Journal of Business \& Management, 9(17): 65-82.

Nderitu, M., Njeru, A. K. \& Waiganjo, E. W. (2017b). Influence of financial literacy on growth in wealth of investment groups in Kenya. European Journal of Business and Management, 9(14): 73-92.

Nerudova, D., \& Bohusova, H. (2008). The empirical study of the SMEs position in the process of IFRS for SME 
application in the Czech Republic. Economics \& Management, (13): 163-169.

Ogutu, V. O. (2014) Influence of Investment Groups on Creation of Small and Medium Size Enterprises in Nairobi County. International Journal of Science and Research, 4(4):1828-1861.

Olasupo, S. F., Sorunke, O. A., \& Olawuyi, L. (2016). Statutory auditing and performance of small and medium scale enterprises in Lagos State, South WestNigeria. International Journal of Academic Research in Business and Social Sciences, 6(9): 58-67.

Onyuma, S. O. \& Ochieng', I. E. (2017). Moderating Effect of Economic Growth on the Relationship between Foreign Private Capital Flows and Securities Market Development: Evidence from Kenya. Journal of Developing Country Studies, 7 (8): 1-13.

Onyuma, S. O. \& Kibet, L. K. (2017). Does Economic Growth Influences the Relationship Between Financial Intermediaries and Securities Market Development in Kenya? Journal of Economics and Sustainable Development, 8(16): 19-30.

Onyuma, S. O. (2020) Membership structure and financial performance of investment Groups investing in securities market in Kenya. Journal of Economics \& Sustainable Development, 11(10): (forthcoming).

Oviedo A. M. (2009). Economic Informality: causes, costs and policies - a literature survey. Working Paper No. 167. Washington DC: World Bank.

Rand, J., \& Torm, N. (2012). The benefits of formalization: Evidence from Vietnamese manufacturing MSEs. World development, 40(5): 983-998.

Sian, S., \& Roberts, C. (2009). UK small owner-managed businesses: accounting and financial reporting needs. Journal of Small Business and Enterprise Development, 16(2): 289-305.

Tyrrall, D., Woodward, D., \& Rakhimbekova, A. (2007). The relevance of international financial reporting standards to a developing country: Evidence from Kazakhstan. The international Journal of accounting, 42(1): 82-110.

Wainaina,T. (2012). Reinventing your Investment Group: Transformation to wealth creation. Retrieved from http://www.unaitas.com

Zaman, M., \& Gadenne, D. (2002). A model for best financial and cost accounting practices in SMEs: an exploratory study. Small Enterprise Research, 10(1): 15-31. 